\title{
Biological and hydrographical responses to tropical cyclones (typhoons) in the continental shelf of the Taiwan Strait
}

\author{
Fuh-Kwo Shiah $^{\mathrm{a}, \mathrm{b}, *}$, Shi-Wei Chung ${ }^{\mathrm{b}}$, Shuh-Ji Kao ${ }^{\mathrm{a}}$, \\ Gwo-Ching Gong ${ }^{c}$, Kon-Kee Liu ${ }^{\mathrm{a}}$ \\ a Institute of Oceanography, National Taiwan University, Taipei, Taiwan, ROC \\ ${ }^{\mathrm{b}}$ The National Center for Ocean Research, National Taiwan University, Taipei, Taiwan, ROC \\ ${ }^{\mathrm{c}}$ Department of Oceanography, National Taiwan Ocean University, Keeloung, Taiwan, ROC
}

Received 15 April 1999; accepted 30 November 1999

\begin{abstract}
A survey on the changes of chemical and biological parameters in the continental shelf of the south East China Sea, northwest of Taiwan was conducted shortly after the passage of tropical cyclone Herb in the summer, 1996. A transect with four sampling stations was visited twice to explore temporal and spatial variability. Data collected from the same transect in the summer of 1994 and 1997 indicated that the study area was a typical oligotrophic system with lack of typhoon disturbance. The results showed that after the cyclone event, all the values of the measured chemical and biological parameters were much greater than those derived from normal summer periods. The depth $(40 \mathrm{~m})$ integrated values of chlorophyll- $a$, nitrate and particulate organic nitrogen concentrations increased 18, 169 and $73 \%$, respectively. More significantly, primary production, particulate organic carbon concentrations and bacterial production as well as biomass increased at least two-fold. Wind mixing, re-suspension and terrestrial runoff which resulted from cyclone passage probably were the three major processes resulting in these phenomena, although their relative importance could not be distinguished clearly in this study. The magnitude of the enhancement of measured parameters varied with time and space, suggesting that the study area was at a highly unsteady status after the passage of the typhoon. This study demonstrated that the shelf ecosystem became more productive after the cyclone event, but more research is required to explore the fate of these newly formed organic substances. (C) 2000 Elsevier Science Ltd. All rights reserved.
\end{abstract}

Keywords: East China Sea; Primary production; Chlorophyll- $a$; Inorganic nutrients; Particulate organic matter; Bacterial production

\footnotetext{
${ }^{*}$ Corresponding author. Tel./fax: 011-886-2-2369-5746.
}

E-mail address: fkshiah@ccms.ntu.edu.tw (F.-K. Shiah). 


\section{Introduction}

The continental shelf has been viewed as an ecosystem that plays an important role in regulating global carbon cycling due to its high primary productivity (Mantoura et al., 1991; Jickells, 1998). Many interdisciplinary programs, such as the shelf edge exchange processes (SEEP) (Biscaye et al., 1994) and Kuroshio edge exchange processes (KEEP) (Wong et al., 2000), have concentrated on their research goals in the shelves of the Atlantic Bight and the East China Sea, respectively. In these programs, routine field surveys have been conducted in a way to address temporal variability of various parameters. These include the seasonal changes of external physical forces (i. e., monsoon), nutrient inputs (from riverine discharge and water column mixing), planktonic trophodynamics and organic carbon export from the upper water column. On the other hand, possible impacts from the episodic events such as tropical cyclones (aka. typhoons), on the shelf ecosystem have been neglected until recently (Chang et al., 1996; Dickey et al., 1998b and citations therein). On an average, at least 24 typhoons occurred at the northwestern Pacific and the South China Sea every year (data source, The Central Weather Bureau, Taiwan).

As mentioned by Chang et al. (1996) and others, it is somehow difficult to study typhoons' impacts for two major reasons. The occurrence and path of typhoons cannot be predicted accurately. In addition, the severe weather condition, even several days after the passage of typhoons, makes shipboard measurements extremely difficult, especially at more offshore areas. It is expected that in many shallow (i.e., bottom depth $<200 \mathrm{~m}$ ) aquatic ecosystems, physical disturbance resulting from typhoons may cause sequential changes of chemical phenomena and thus enhance biological productivity. However, there are not many reports in describing their spatial and temporal variations in details. More information of episodic events that affect the continental shelf ecosystems at large as well as in fine scales is essential for understanding their roles in the global biogeochemical cycles.

During the late July of 1996, two strong typhoons (Graff and Herb) swept through Taiwan, consecutively. A cruise was designed originally to study the nutrient fluxes at the continental shelf west of Taiwan (i.e., the Taiwan Strait), but we also took this opportunity to observe the variations of chemical and biological variables (see below) after the passage of these two typhoons. In addition, to address the shorttermed temporal variation of measured variables, each station was sampled twice (see below). The chemical and biological variables recorded on the shelf were greatly enhanced after the typhoon event when compared with the data collected from the same area during non-typhoon periods.

\section{Material and methods}

\subsection{Study area and sampling}

Data were collected from the three cruises conducted on the same transect on the continental shelf (bottom depth ca. 70-100 m) of the Taiwan Strait (Fig. 1) during 


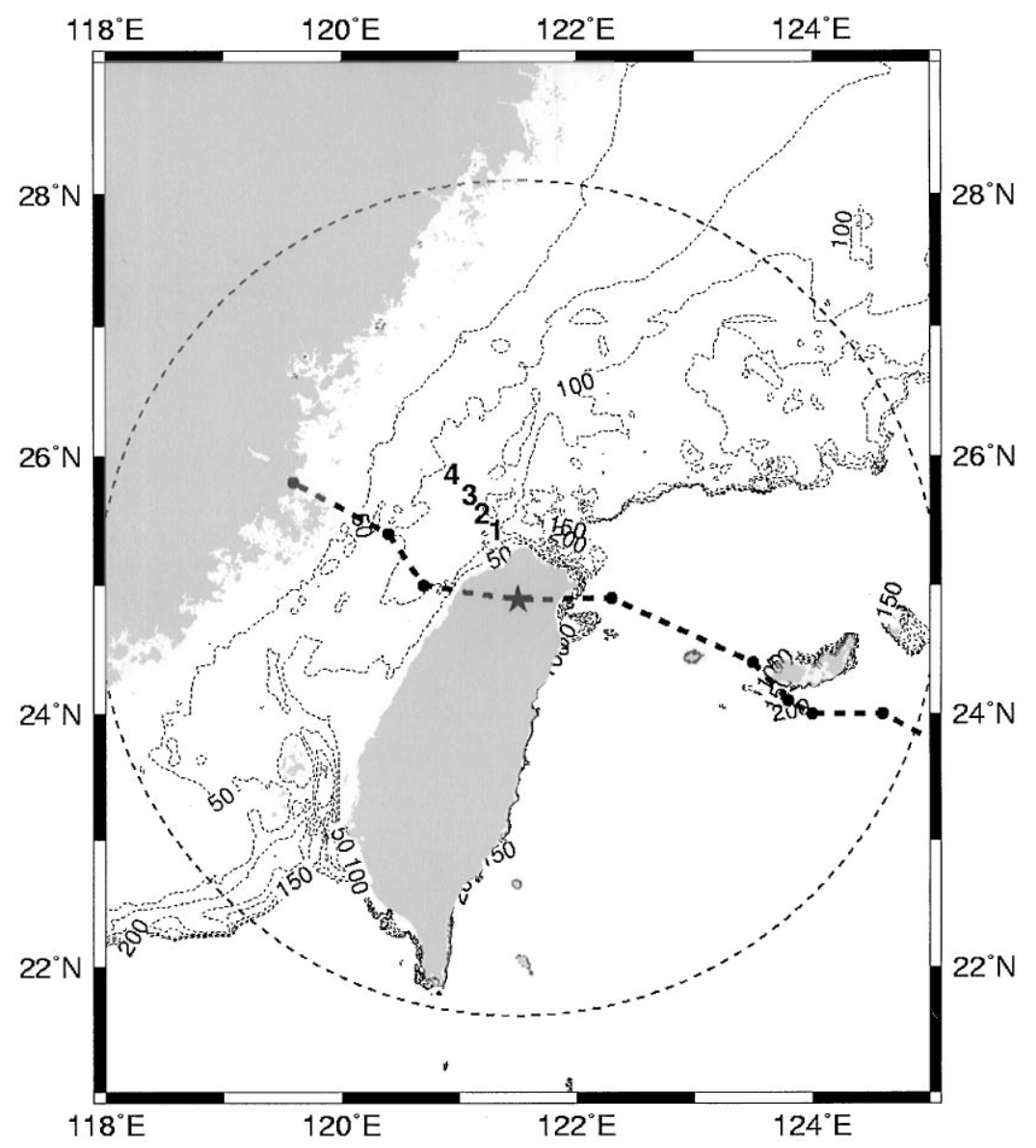

Fig. 1. Map of the Taiwan Strait showing sampling stations. The bold dotted line and the symbol star indicated the pathway of typhoon Herb and its central position on 11:00 PM; 31 July 1996, respectively (data source, The Central Weather Bureau, Taiwan). Dashed lines indicate bottom depths in meter.

the summer seasons of 1994, 1996 and 1997. There were four sampling stations on the transect. The 1996 cruise was conducted 4 days after typhoon Herb (wind speed $53 \mathrm{~m} \mathrm{~s}^{-1}$ ) had swept through northern Taiwan (Fig. 1; July 29-31, 1996). The four sampling stations were visited twice with an interval of $43.47 \mathrm{~h}$, exactly 3.5 times the period of the $\mathrm{M}_{2}$ tide, which is dominant in this region (Tang and Lee, 1996). The repeated measurements at the same station represented the opposite phase of a $\mathbf{M}_{2}$ tidal cycle. The 1994 and the 1997 cruises represented the normal summer and there was no typhoon one month prior to those cruises. For the 1994 cruise, sampling was performed only once at each station; but on the 1997 cruise, each station was visited twice with an interval of $43.47 \mathrm{~h}$. For simplicity, the data we collected were named as $\mathrm{T}_{94}$ (for the 1994 cruise), $\mathrm{T}_{96} 1$ and $\mathrm{T}_{96} 2$ (for the 1996 cruise) as well as $\mathrm{T}_{97} 1$ and $\mathrm{T}_{97} 2$ (for the 1997 cruise) thereafter. 
Seawater was collected from a SeaBird CTD-General Oceanic Rosette assembly with 20-1 Go-Flo bottles. Light intensity was measured with a light meter (QSP200L; Biospherical), while the depth of the euphotic zone was defined as $1 \%$ of the surface light level. The euphotic zone depths during normal and typhoon periods were 35-55 m (Fig. 2G) and 15-40 m (Fig. 2H), respectively. The depth of the mixed layer was determined as the depth where its temperature was $0.5^{\circ} \mathrm{C}$ lower than the surface temperature (Levitus, 1982).

\subsection{Primary production}

Primary production was measured by the ${ }^{14} \mathrm{C}$ assimilation method (Parsons et al., 1984). In brief, two light and one dark $250-\mathrm{ml}$ clean PC bottles were filled with water samples taken from the euphotic zone. After inoculation with $\mathrm{H}^{14} \mathrm{CO}_{3}^{-}$(final conc., $10 \mu \mathrm{Ci} \mathrm{ml}{ }^{-1}$ ), samples were incubated for 3-4 h in a self-designed tank with an artificial light source. Water temperature was maintained with running seawater. To simulate light intensity, incubation bottles were wrapped with neutral density filters (LEE filters). Following the retrieval, the water samples were immediately filtered through Whatman $25 \mathrm{~mm} \mathrm{GF/F}$ filters under low light and low pumping pressure $(<100 \mathrm{mmHg})$. The filters were then placed in scintillation vials and $0.5 \mathrm{ml}$ of $0.5 \mathrm{~N}$ $\mathrm{HCl}$ was added to remove residual $\mathrm{H}^{14} \mathrm{CO}_{3}^{-}$. Radioactivity was counted in a liquid scintillation counter (Packard 1600) after the addition of $10 \mathrm{ml}$ scintillation cocktail (Ultima Gold, Packard) into the vials.

\subsection{Bacterial biomass, production and growth rates}

Bacterial abundance was determined by using the Acridine Orange Direct Count method (Hobbie et al., 1977). Samples fixed with glutaraldehyde (final conc., 1\%) were stained with acridine orange (final conc., $0.01 \%$ ) for $2 \mathrm{~min}$ before being filtered through $0.2 \mu \mathrm{m}$ polycarbonate filters prestained with an Irgalan black solution. Slides were enumerated by epifluorescence microscopy (Zeiss, Axioplan). Biomass was calculated using a carbon conversion factor of $2 \times 10^{-14} \mathrm{~g} \mathrm{C}$ cell $^{-1}$ (Ducklow and Carlson, 1992). Bacterial production was estimated by the method of ${ }^{3} \mathrm{H}$ thymidine (Fuhrman and Azam, 1982) incorporation with a conversion factor of $1.18 \times 10^{18}$ cells mol thymidine ${ }^{-1}$ (Cho and Azam, 1988). Triplicate $30-40 \mathrm{ml}$ aliquots of water samples were incubated with ${ }^{3} \mathrm{H}-[$ methyl]-thymidine (S. A., 6.7 $\mathrm{Ci} \mathrm{mmol}^{-1}$; final conc., $20 \mathrm{nM}$ ) in clean polycarbonate tubes at in situ temperature. Reaction was stopped by adding formaldehyde (final conc., 1\%). The killed samples including time zero controls were filtered through $0.2 \mu \mathrm{m}$ cellulose nitrate filters. These filters were then rinsed three times each with ice-cold

Fig. 2. Depth contour of measured variables derived from non-typhoon (left panels; $\mathrm{T}_{94}$ data) and typhoon (right panels; $\mathrm{T}_{96} 2$ data) periods. Note that the $Y$-axis of panels $\mathrm{E}$ vs. F, G vs. H, I vs. J and K vs. $\mathrm{L}$ are different. Solid line in panels $\mathrm{G}$ and $\mathrm{H}$ indicated the euphotic zone depth. 
Sampling Station
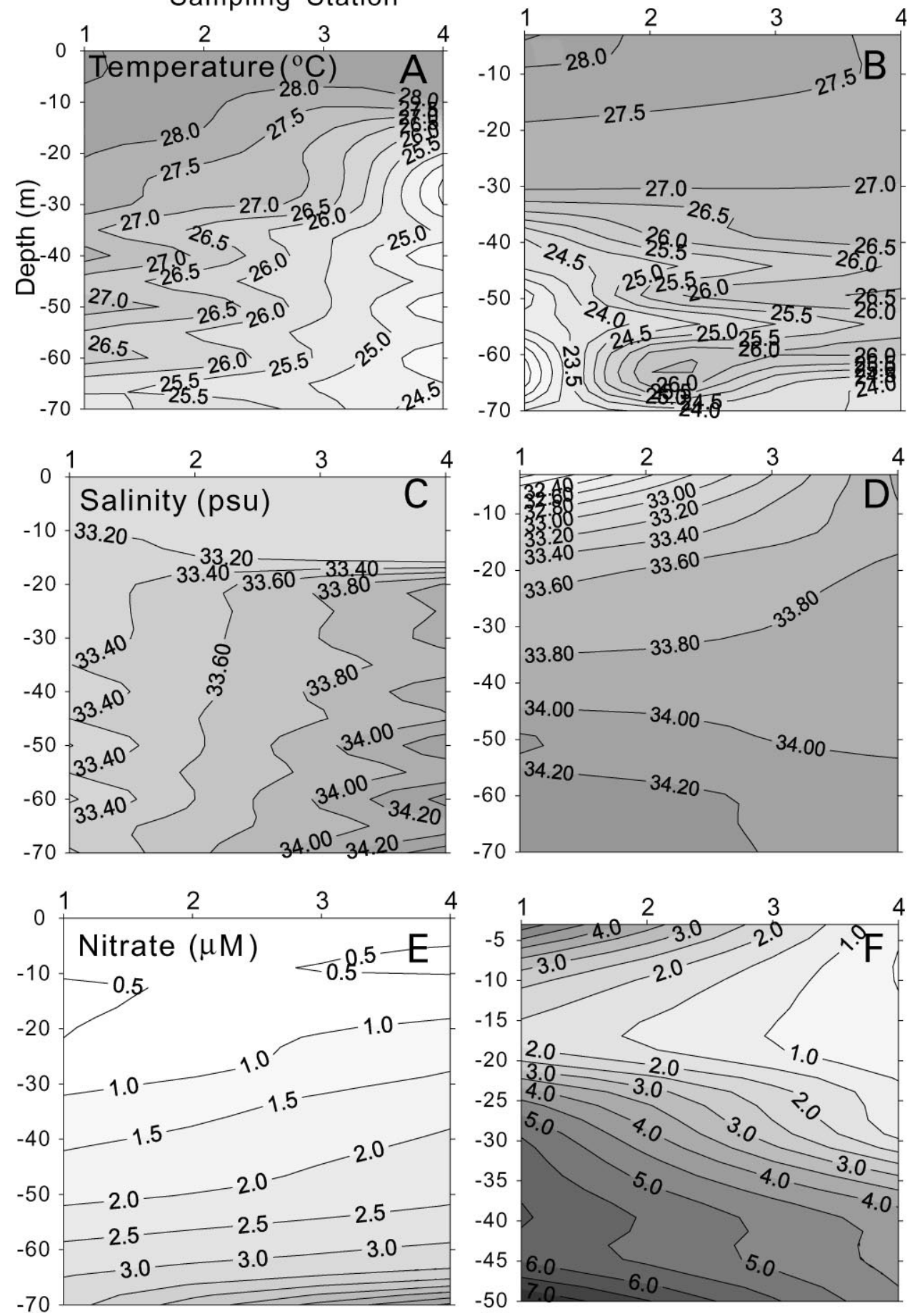

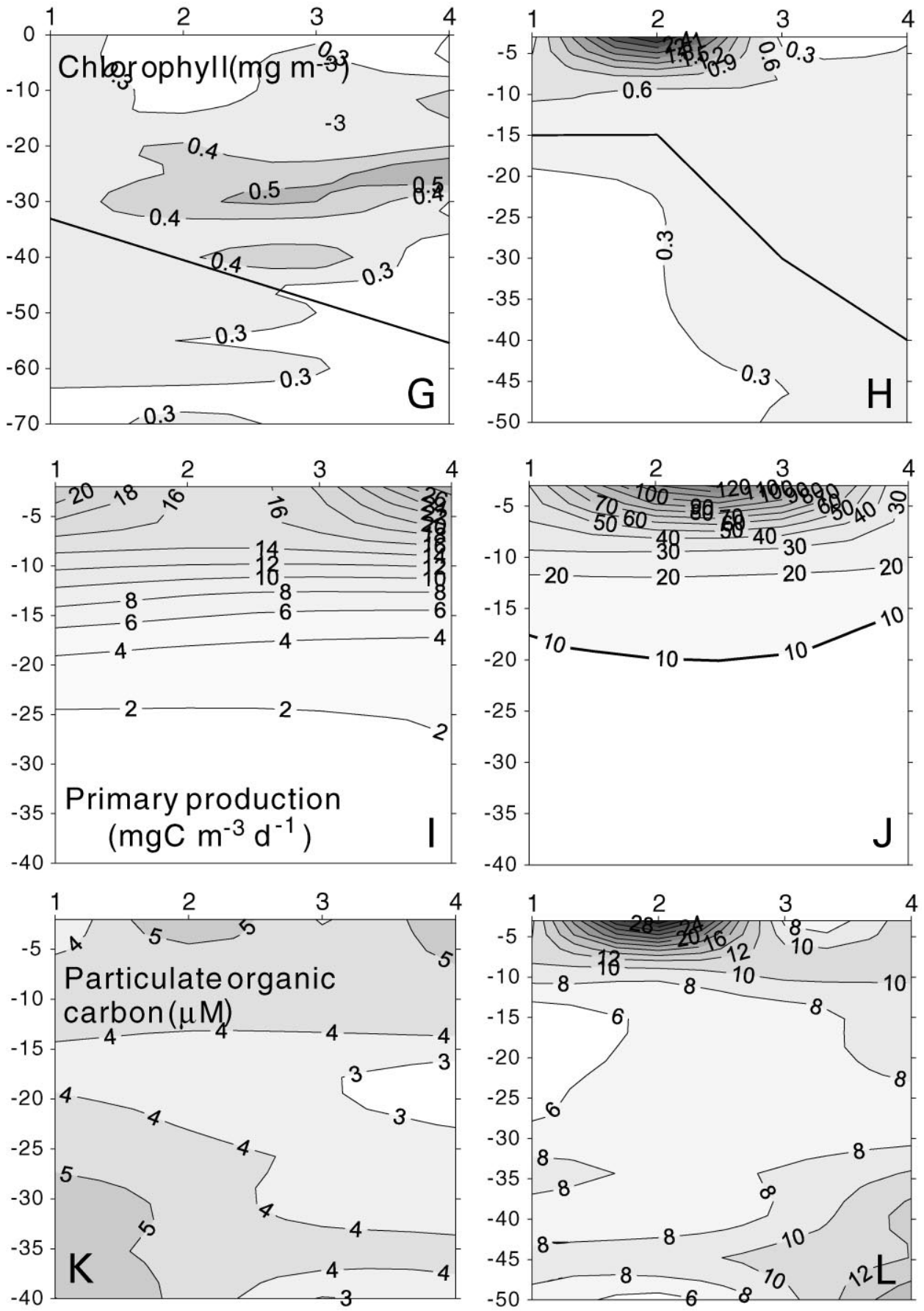

Fig. 2. (Continued.) 

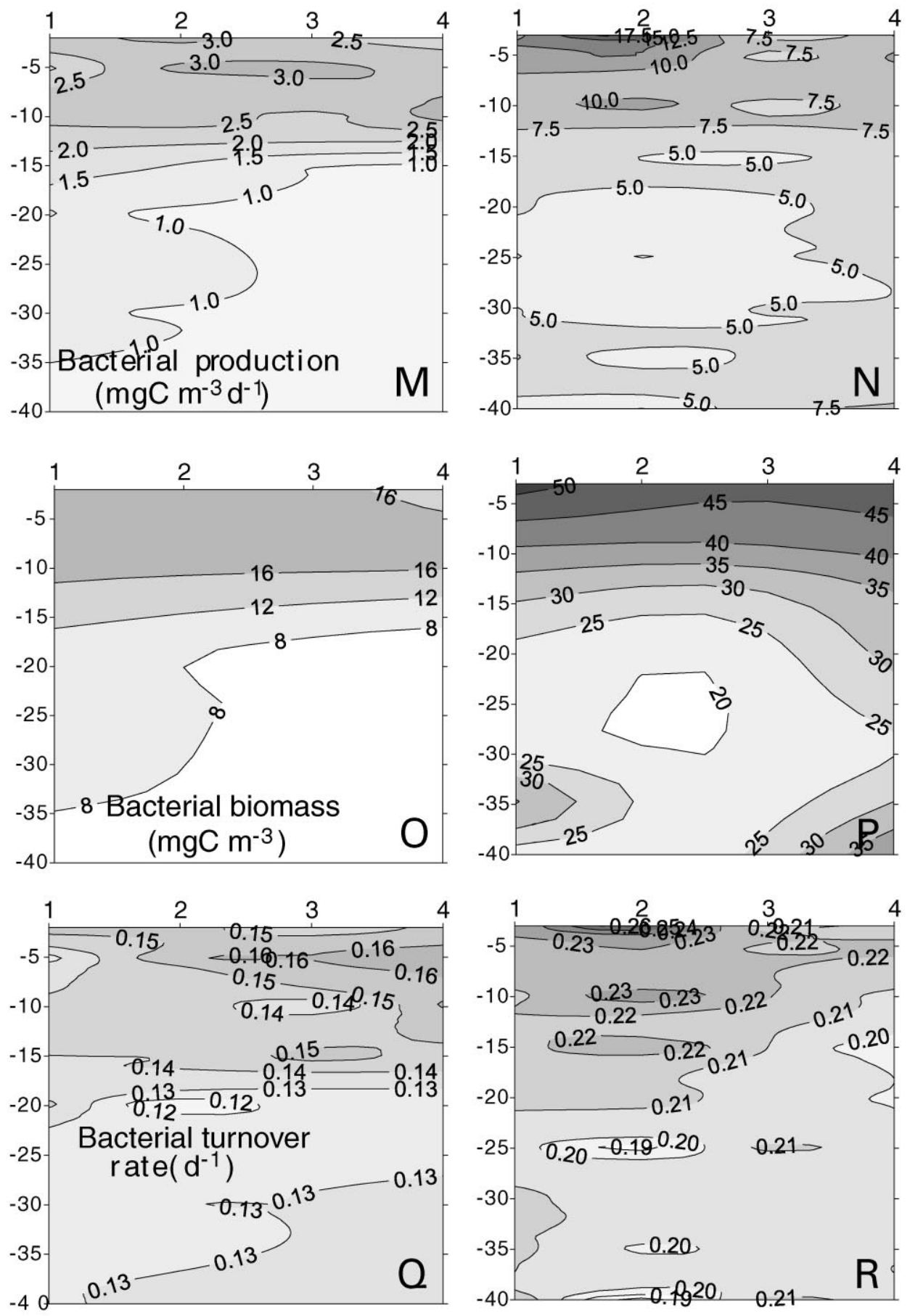

Fig. 2. (Continued.) 
$5 \%$ trichloroacetic acid and ice-cold $80 \%$ ethyl alcohol sequentially. Scintillation cocktail ( $6 \mathrm{ml}$; Ultima Gold, Packard) was added after the dried filters were dissolved completely in $0.5 \mathrm{ml}$ of ethyl acetate. Radioactivity was determined by liquid scintillation counting (Packard 1600). Bacterial turnover rates were calculated by dividing bacterial production by bacterial biomass.

\subsection{Particulate organic carbon and nitrogen concentrations}

Water samples $(0.5-1.01)$ for particulate organic carbon (POC) and nitrogen (PN) measurements were filtered through a $200 \mu \mathrm{m}$ mesh to remove zooplankton. After filtration ( $25 \mathrm{~mm} \mathrm{GF} / \mathrm{F}$ filters; pumping pressure $<100 \mathrm{mmHg}$ ), the samples were wrapped in aluminum foil and stored at $-4^{\circ} \mathrm{C}$. Both the filters and the aluminum foils had been pre-combusted at $550^{\circ} \mathrm{C}$ for $1 \mathrm{~h}$ before filtration. POC and PN concentrations were measured by a CHN analyzer (Fisons; NA1500) after samples had been dried and acid-fumed.

\subsection{Chlorophyll-a and nitrate concentrations}

Chlorophyll- $a$ and nitrate concentrations were measured following the methods of Parsons et al. (1984). Water samples for nutrient analyses were subsampled with clean $100 \mathrm{ml}$ polypropylene bottles and frozen immediately with liquid nitrogen. Nitrate was analyzed with a self-designed flow injection analyzer (Gong et al., 1995) and was reduced to nitrite with a cadmium wire, which was activated with a copper sulfate solution. The detection limit for this method is $0.25 \mu \mathrm{M}$. For chlorophyll- $a$, 2.51 of seawater were filtered through $47 \mathrm{~mm}$ Whatman GF/F filters which were then immediately stored at $-20^{\circ} \mathrm{C}$. Back at the laboratory, the filters were ground in $10 \mathrm{ml}$ of $90 \%$ acetone followed by extraction in a $4^{\circ} \mathrm{C}$ shaking incubator for $2 \mathrm{~h}$. After centrifugation at $1000 \mathrm{rpm}$ for $5 \mathrm{~min}$, the concentrations of chlorophyll in the supernatant were measured on a Turner fluorometer (model 10-AU-005).

\subsection{Data analyses}

The integrated data set was generated by integrating measured variables down to $40 \mathrm{~m}$ by trapezoid method. Statistical analysis was performed with Macintosh software StaView ${ }^{\mathrm{TM}}$ II (Abacus Concepts, Inc.).

\section{Results}

Fig. 2 depicts parts of the depth contours of measured variables collected from the non-typhoon (cruise 1994; $\mathrm{T}_{94}$ ) and the typhoon (cruise 1996; $\mathrm{T}_{96} 2$ ) periods. The individual values of the measured variables derived from the cruise of 1997 (nontyphoon period; $\mathrm{T}_{97} 1$ and $\mathrm{T}_{97} 2$ ) were very similar to those of $\mathrm{T}_{94}$, both in terms of temporal and spatial variability. The comparison of all data sets will be shown with depth $(40 \mathrm{~m})$ integrated data in the next section. Temperatures in the upper water 
column $(0-50 \mathrm{~m})$ ranged from 24 to $28^{\circ} \mathrm{C}$. The depths of the mixed layer $\left(Z_{\mathrm{m}}\right)$ of $\mathrm{T}_{94}$ were shallow (15-20 m; Fig. 2A) with a well-defined thermocline. The $Z_{\mathrm{m}}$ of $\mathrm{T}_{96} 2$ could be observed but the magnitude of stratification seemed to be much weaker (Fig. 2B). With one exception, salinities of all sampling stations were $>33.0$ psu (Fig. 2C). The low salinity ( $<32.0$ psu; Fig. 2D) observed in the station adjacent to Taiwan coast (i.e. station 1) of $\mathrm{T}_{96} 2$ indicated the influence from the runoffs.

Nitrate concentrations (NO; Fig. 2E) in the upper $20 \mathrm{~m}$ were low $(<0.50 \mu \mathrm{M})$ for $\mathrm{T}_{94}$, and then increased to ca. $1.65 \mu \mathrm{M}$ at the bottom of $Z_{\mathrm{e}}$; the nitracline was obvious and located at a depth of $20 \mathrm{~m}$. For $\mathrm{T}_{96} 2$, more than half of (13 out of 20 ; Fig. 2F) the NO data in the upper $20 \mathrm{~m}$ were $>0.60 \mu \mathrm{M}$; the highest value of surface NO $(5.3 \mu \mathrm{M}$; Fig. $2 \mathrm{~F})$ was recorded in station 1 with the lowest salinity.

The euphotic zone depths after the typhoon $(15-40 \mathrm{~m})$ became shallower than those derived from the normal summer $(35-55 \mathrm{~m})$. High concentrations of particles resulted from resuspension, river runoffs and planktonic organisms growth (see below) after typhoon might block significant amount of sunlight penetrating into the water column. Chlorophyll- $a$ concentrations (Chl- $a$ ) of normal summer condition were low (0.20-0.60 mg Chl- $\left.a \mathrm{~m}^{-3}\right)$ with a subsurface chlorophyll maximum (SCM) located at ca. $25 \mathrm{~m}$ (Fig. 2G). For $\mathrm{T}_{96} 2$, Chl- $a$ decreased with depth with no perceptible SCM, and about 15\% (6 out of 40; Fig. $2 \mathrm{H}$ ) of the Chl- $a$ data within $Z_{\mathrm{e}}$ were $>0.60 \mathrm{mg} \mathrm{Chl}-a \mathrm{~m}^{-3}$ with a highest value of $3.0 \mathrm{mg} \mathrm{Chl-} a \mathrm{~m}^{-3}$. The depth profiles of primary production (PP) derived from both cruises showed the same trend with the highest values appearing near the surface, and then decreasing with the depth. Surface $P P$ of $\mathrm{T}_{94}$ and $\mathrm{T}_{96} 2$ cruises ranged between 15-30 and 25-201 $\mathrm{mg} \mathrm{C} \mathrm{m}^{-3} \mathrm{~d}^{-1}$, respectively (Figs. 2I and J).

Particulate organic carbon (POC) concentrations showed dramatic difference on these two cruises. During the non-typhoon period, POC seldom exceeded $6.0 \mu \mathrm{M}$ (Fig. 2K). After typhoon, most of the POC were $>7.0 \mu \mathrm{M}$ with a maximum of $31.4 \mu \mathrm{M}$ (Fig. 2L) at station 2. The POC: PN molar ratios $(5.3-7.8 \mathrm{~mol} \mathrm{C}$ $\mathrm{mol}^{-1} \mathrm{~N}^{-1}$ ) derived from $\mathrm{T}_{94}, \mathrm{~T}_{97} 1$ and $\mathrm{T}_{97} 2$ were quite constant over stations, and their relationship was $\mathrm{POC}=1.0+8.31( \pm 1.06) \times \mathrm{PN}\left(n=104, p<0.01, R^{2}=0.92\right)$. The ratios derived from $\mathrm{T}_{96} 2$ (and $\mathrm{T}_{96} 1$ ) varied from 6.3 to 40.4, and more than half (36 out of 64; data not shown) of these ratios exceeded $9.0 \mathrm{~mol} \mathrm{C} \mathrm{mol}{ }^{-1} \mathrm{~N}^{-1}$ (see also Table 1).

All of the bacterial variables measured from the typhoon period (Figs. 2N, P and R) were at least 2 times higher than those recorded from the non-typhoon period (Figs. 2M, O and Q). Bacterial production (BP) and bacterial biomass (BB) recorded from $\mathrm{T}_{94}$ and $\mathrm{T}_{96} 2$ ranged between $0.6-3.3$ and $2.1-18.7 \mathrm{mg} \mathrm{C} \mathrm{m}^{-3} \mathrm{~d}^{-1}$ as well as 5-21 and 11-70 $\mathrm{mg} \mathrm{C} \mathrm{m}^{-3}$, respectively. Note that the depth profiles of BP and $\mathrm{BB}$ recorded from these two cruises were quite different. During the non-typhoon period, BP and BB were higher in the upper water column and then decreased with depth (Figs. 2M and O). After the typhoon event, BP and BB were high in the surface waters, then decreased with depth and then increased again in the waters near the bottom (Figs. $2 \mathrm{~N}$ and $\mathrm{P}$ ). The lowest individual bacterial turnover rates $\left(\mu_{\mathrm{i}}=\mathrm{BP} / \mathrm{BB}\right)$ of $\mathrm{T}_{96} 2\left(0.18-0.27 \mathrm{~d}^{-1}\right.$; Fig. $\left.2 \mathrm{R}\right)$ were higher than the highest value of $\mathrm{T}_{94}$, which varied from 0.10 to $0.17 \mathrm{~d}^{-1}$ (Fig. 2Q). 
Table 1

List of the values of average (ave), standard deviation (std) and coefficient of variation $(\mathrm{CV}=\mathrm{std} / \mathrm{ave} \times$ $100 \%$, in bold Italic) of the depth $(40 \mathrm{~m})$ integrated variables derived from normal $(1994+1997)$ and typhoon (1996) periods

\begin{tabular}{|c|c|c|c|c|}
\hline Items & Units & $\begin{array}{l}\text { Normal } \\
\text { Ave } \pm \text { std; CV }\end{array}$ & $\begin{array}{l}\text { Typhoon } \\
\text { Ave } \pm \text { std; CV }\end{array}$ & Difference $^{\mathrm{a}}$ \\
\hline Nitrate & $\mathrm{mmol} \mathrm{m}^{-2}$ & $25 \pm 7 ; 27 \%$ & $66 \pm 50 ; 77 \%$ & $+169 \%$ \\
\hline Chlorophyll- $a$ (Chl- $a)$ & $\mathrm{mg} \mathrm{Chl} \mathrm{m}^{-2}$ & $16 \pm 3 ; 22 \%$ & $19 \pm 7 ; 39 \%$ & $+18 \%$ \\
\hline Primary Production (PP) & $\mathrm{mgC} \mathrm{m} \mathrm{C}^{-2} \mathrm{~d}^{-1}$ & $102 \pm 17 ; \mathbf{1 7 \%}$ & $660 \pm 506 ; 77 \%$ & $+545 \%$ \\
\hline $\mathrm{PP} / \mathrm{Chl}-a$ & $\mathrm{mg} \mathrm{C} \mathrm{mg} \mathrm{Chl}{ }^{-1} \mathrm{~m}^{-2} \mathrm{~d}^{-1}$ & $6.4 \pm 1.3 ; 20 \%$ & $32.2 \pm 10.2 ; 32 \%$ & $+403 \%$ \\
\hline Particulate organic carbon & $\mathrm{mmol} \mathrm{C} \mathrm{m}-2$ & $178 \pm 18 ; \mathbf{1 0 \%}$ & $524 \pm 231 ; 44 \%$ & $+193 \%$ \\
\hline Particulate organic nitrogen & $\mathrm{mmol} \mathrm{N} \mathrm{m}^{-2}$ & $26 \pm 3 ; 11 \%$ & $46 \pm 9 ; 20 \%$ & $+73 \%$ \\
\hline Bacterial Production (BP) & $\mathrm{mg} \mathrm{C} \mathrm{m} \mathrm{m}^{-2} \mathrm{~d}^{-1}$ & $35 \pm 5 ; 13 \%$ & $160 \pm 31 ; 19 \%$ & $+359 \%$ \\
\hline Bacterial Biomass (BB) & $\mathrm{mg} \mathrm{C} \mathrm{m}{ }^{-2}$ & $260 \pm 34 ; 13 \%$ & $753 \pm 153 ; 20 \%$ & $+190 \%$ \\
\hline Bacterial $^{\mathrm{b}}$ turnover rates $\left(\mu_{\mathrm{z}}\right)$ & $\mathrm{d}^{-1}$ & $0.13 \pm 0.01 ; 2 \%$ & $0.22 \pm 0.02 ; 7 \%$ & $+59 \%$ \\
\hline $\mathrm{BP}: \mathrm{PP}$ ratio & $\%$ & $35 \pm 7 ; 21 \%$ & $32 \pm 15 ; 46 \%$ & $-8 \%$ \\
\hline
\end{tabular}

${ }^{\text {a }}$ Calculated as (typhoon data-normal data)/normal data $\times 100 \%$; all significant at $p=0.05$ level except Chl- $a$ and BP : PP ratios.

${ }^{\mathrm{b}}$ Calculated as $\mathrm{BP} / \mathrm{BB}$.

The depth $(40 \mathrm{~m})$, integrated data of all measured variables are shown in Fig. 3. During the normal season, all variables were quite consistent, both in terms of tidal $\left(\mathrm{T}_{97} 1\right.$ vs. $\left.\mathrm{T}_{97} 2\right)$ and the inter-annual ( $\mathrm{T}_{94}$ vs. $\mathrm{T}_{97} 1$ and $\left.\mathrm{T}_{97} 2\right)$ variability. Table 1 indicated that after pooling of these three normal periods' data sets, the coefficient of variation (i.e., $\mathrm{CV}$ ) of the measured variables were all $<30 \%$.

On the other hand, after the passage of typhoon, the values of all measured variables, with the exceptions of Chl-a and BP : PP ratios (Table 1), increased substantially by at least $50 \%$. In addition, temporal variability of each variable, as indicated by the $\mathrm{CV}$ values, also increased by at least $50 \%$ (Table 1 ) when compared with the $\mathrm{CV}$ of their counterparts derived from the normal periods. Note also that during typhoon season (i.e. $\mathrm{T}_{96} 1$ and $\mathrm{T}_{96}$ ), the highest values of algal biomass and activities (Figs. 3B-D) were not in phase with those of nitrate (Fig. 3A). Furthermore, on average, values of POC tended to decrease seawards (Fig. 3E), while PN showed the opposite trend (Fig. 3F) during the typhoon period. Finally, the ratios of BP vs. PP during both the normal (35 \pm 7$)$ and typhoon (32 \pm 15$)$ periods were very similar (Table 1), although the CV of the latter was significantly higher.

\section{Discussion}

The Taiwan Strait Waters (TSW) originates from the oligotrophic South China Sea (see Shaw, 1992 for review). The top layer $(20-30 \mathrm{~m}$ ) of the TSW is characterized by low concentrations of NO and Chl- $a$ as well as strong stratification (Gong et al., 1992) during summer. The collected NO and Chl- $a$ data as well as the distinct SCM phenomenon from non-typhoon periods (cruises 1994 and 1997) fit within the results reported by Gong et al. $(1992,1996)$ that represented the normal 

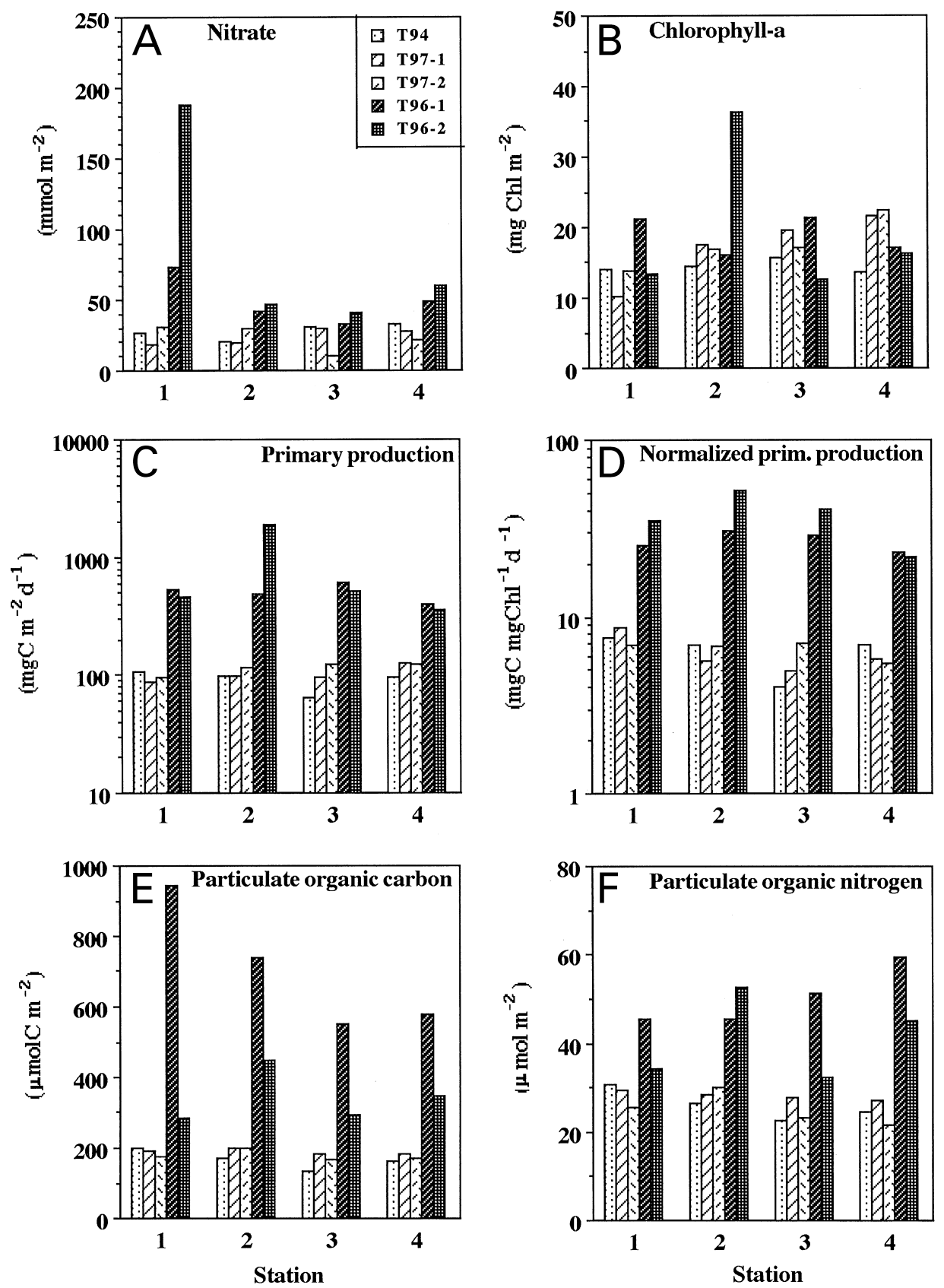

Fig. 3. Depth $(40 \mathrm{~m})$ integrated values of measured variables derived from non-typhoon $\left(\mathrm{T}_{94}, \mathrm{~T}_{97} 1\right.$, and $\left.\mathrm{T}_{97} 2\right)$ and typhoon $\left(\mathrm{T}_{96}\right.$ and $\left.\mathrm{T}_{96} 2\right)$ periods. See text for the explanation of each symbol. Note that the $Y$-axis of panels $\mathrm{C}$ and $\mathrm{D}$ are in $\log$ scale for better presentation. 

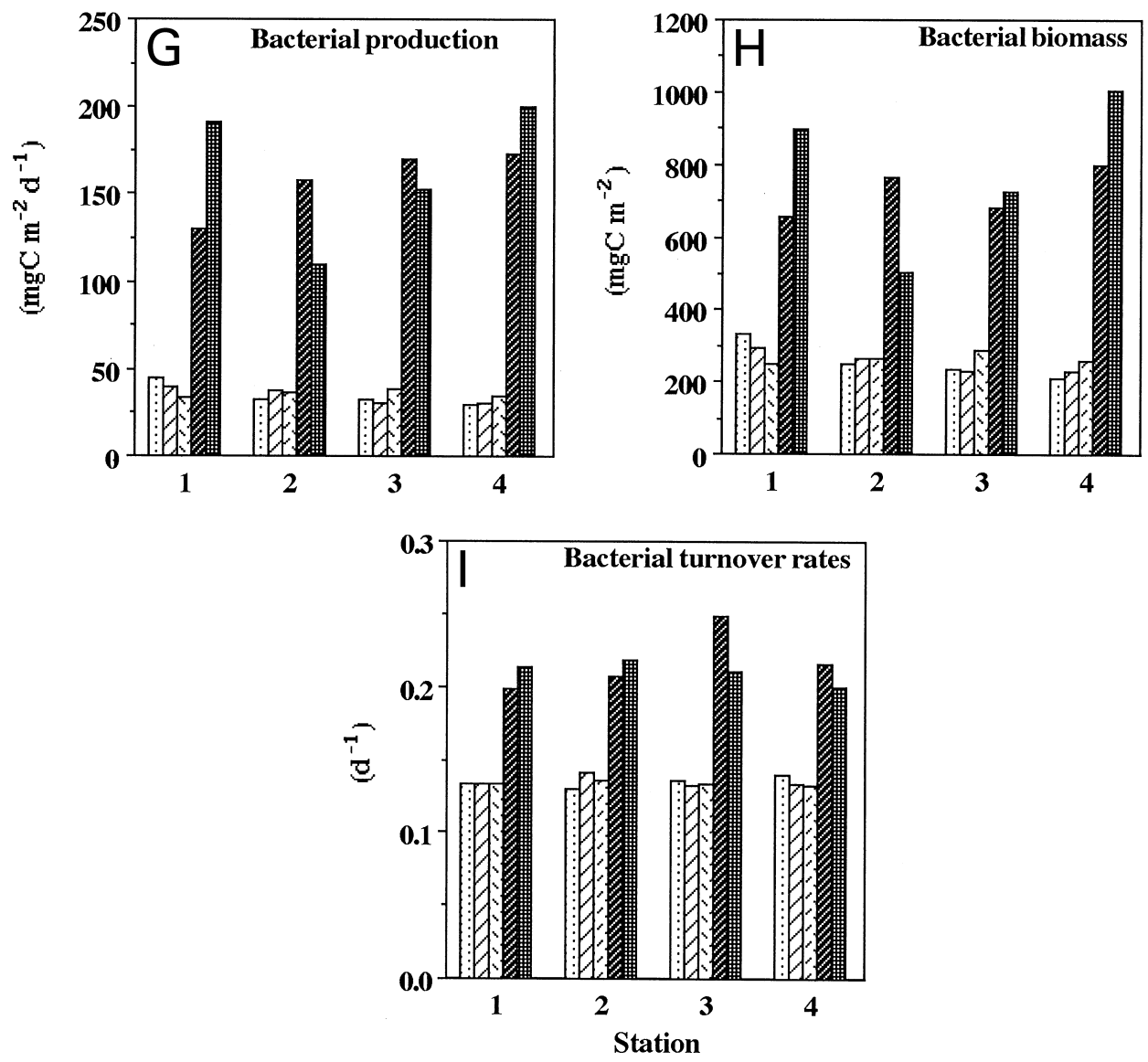

Fig. 3. (Continued.)

summer conditions of the TSW. Bacterial measurements derived from $\mathrm{T}_{94}, \mathrm{~T}_{97} 1$ and $\mathrm{T}_{97} 2$ were similar to the values derived from the oligotrophic western equatorial Pacific (Shiah et al., 1998) and the oligotrophic Kuroshio waters (Shiah, 1999; Shiah et al., 1999, 2000). Our study further showed that PP and inventory of POC (and PN) were low during summer period without the interference of typhoons.

Mesoscale eddy may confound our observations and caused variations among stations and cruises. In a normal summer condition, the possibility for mesoscale eddy to occur in the Taiwan Strait is quite low due to its small area and the prevailing southwest monsoon (Jan Sen, The National Center for Ocean Research, Taiwan; personal communication). As to the possibility of forming eddy after the passage of typhoon, we did not have data (i.e., mooring-type continuous time-series records; e.g., Dickey et al., 1998a) to explore this issue.

There were two major features in this study. Within the euphotic zone, most, if not all, of the chemical and biological variables recorded from the typhoon periods $\left(\mathrm{T}_{96} 1\right.$ and $\mathrm{T}_{96} 2$ ) were higher than those from non-typhoon periods, in terms of either 
individual or the depth integrated values. After the typhoon event, large temporal variations existed, judging by the higher $\mathrm{CV}$ value of each measured variable (Table 1). This indicates that after the typhoon event, the system seemed to be at a more unsteady state than that of the normal season (see also below).

The enhancement of chemical variables (i.e., $\mathrm{NO}_{3}^{-}$, POC and $\mathrm{PN}$ ) after the typhoon might be due to the effects of either wind mixing or terrestrial inputs or both. However, the relative contribution of these two sources might differ according to the locations of stations. In areas remote from coasts, subsurface waters (bottom depths 70-100 m; Fig. 1) riched in inorganic nutrients (DIN) might outcrop to the surface layer by wind stress driven upwelling (Dickey and Nelson 1996; Dickey et al., $1998 \mathrm{~b})$ due to the storm effects. Higher values of surface and depth integrated NO (Figs. $2 \mathrm{~F}$ and $3 \mathrm{~A}$ ) observed in the offshore stations (Sts. 3 and 4) of $\mathrm{T}_{96} 1$ and $\mathrm{T}_{96} 2$ might have been resulted from these processes. Meanwhile, for the near-shore stations (Sts. 1 and 2), in addition to upwelling processes, higher river discharge rates resulting from heavy precipitation might also increase the surface and depth integrated NO, judging by the low salinity (Fig. 2D) recorded in these stations.

Both the inventories of POC and PN as well as POC : PN ratios showed dramatic difference on the two cruises. During non-typhoon periods, the study area was characterized with low inventories of POC $(<10 \mu \mathrm{M})$ and $\mathrm{PN}(<1.0 \mu \mathrm{M})$. In addition, the molar ratios of POC : PN $(8.31 \pm 1.06)$ were constant and very close to the Redfield ratios over different sampling stations, indicating that most of the POC and PN were biogenic. The stable POC : PN ratios also indicated that the biological system in the TSW was more or less at a steady state. Assuming a conversion factor of $58 \mathrm{mg} \mathrm{C} \mathrm{mg} \mathrm{Chl-} a^{-1}$ (Eppley et al., 1992), then for the 1994 cruise, Chl- $a$ constituted about $43 \%$ of POC inventory (Table 1 ); during typhoon period, this ratio went down to $18 \%$. The sequential changes of the POC : PN ratios (Figs. 3E and $F$ ) revealed that after the typhoon's passage, the organic carbon (and nitrogen) inventory in the water column was in unsteady conditions. Materials with very higher POC : PN ratios (i.e., detrital substance) that derived from terrestrial inputs and sediment resuspension processes (Dickey et al., 1998a) might differentially affect the inventories of POC and PN in the study area. Such influence was more significant in nearshore than in offshore areas and this phenomenon could vanish within two days. On the other hand, the growth of phytoplankton (see below) and other planktonic organisms after typhoon passage might also result in higher POC (and PN) but lower POC : PN ratios. We were not able to distinguish what proportion of POC was derived from biogenic versus detrital (i.e., runoffs and resuspension) sources.

Higher DIN supply rates after a typhoon passage may eventually induce phytoplankton activities (Figs. 3C and D) and increase the biomass within 4-10 days (Chl- $a$; Fig. 3B). This has been documented in coastal ecosystem (Chang et al., 1996 and citations therein) and the Antarctic Ocean (Sakshaug et al., 1991, 1995). However, our study further indicated that the timing and the magnitude of such "blooming" could be quite variable. For example, without repeated observation (at about 2 days interval), one would not detect the large variation of Chl- $a$ in station 2 of $\mathrm{T}_{96} 1$ and $\mathrm{T}_{96} 2$ (Fig. 3B). This indicates that following the typhoon event, the recovery was different for phytoplankton. Chang et al. (1996) demonstrated that 
after typhoon event, the biomass (and growth) of small alge (i.e., $<5 \mu \mathrm{m}$ ) reached a plateau about 3-4 days, while large phytoplankton started to grow after the decline of the small species. Unfortunately, we did not collect phytoplankton samples for taxonomy and size distribution studies.

Bacterial variables increased at least 59\% after the cyclone event. These suggested that substrate required for bacterial growth must be high. There are several plausible reasons for this phenomenon. Chang et al. (1996) showed that the strong turbulence in the water column caused by typhoon might severely damage algal cells and other fragile planktonic organisms. This might result in accumulating labile organic matter in the water column. After the typhoon had passed, the releasing rates of dissolved organic matter (DOM) from the actively growing phytoplankton and other planktonic organisms might increase. Finally, DOM from terrestrial inputs as well as the sediment resuspension might also induce bacterial growth. Ritzrau and Graf (1992, and citations therein) demonstrated that sediment resuspension processes caused by a storm event stimulated benthic bacterial growth. This study observed the same phenomenon (Figs. 2N, P and R), but with further information showing that the enhancement of bacterial growth in the upper water column $(<20 \mathrm{~m})$ was even greater than those in the bottom waters.

\section{Conclusion}

This study demonstrated that the chemical and biological responses to episodic disturbance caused by typhoons in the continental shelf ecosystem were prominent. However, their spatial or temporal distribution patterns were quite heterogeneous. High inputs of DIN due to the cyclone event did made the shelf a more active system in producing particulate and dissolved organic matter. On the other hand, the instantaneous response of bacterial growth suggests that the newly formed labile DOM might be quickly consumed after the algal bloom, as suggested by the similar values of BP : PP ratios during normal and typhoon periods. Therefore, how fast and to what magnitude will these "new production" be consumed within the shelf ecosystems is an interesting question to be answered by further studies. The biological responses (i.e., bloom) after the typhoon vary with time and space. Field observation may provide some insights but seem to be insufficient to cover the details due to "under-sampling" and "bad sea conditions" problems. Satellite remote sensing and mooring (Dickey et al., 1993, 1998a-c; Dickey and Nelson, 1996; McGillicuddy et al., 1998) technique can be very helpful in tracing the algal responses to the disturbances caused by typhoons.

\section{Acknowledgements}

Support for this research was provided by the National Science Council, Taiwan, ROC. We thank Mr. M.J. Tsai for graphic preparation. Cruise assistance from the crew of $\mathrm{R} / \mathrm{V}$ Ocean researcher $I$ is also deeply appreciated. NCOR Contribution \#15. 


\section{References}

Biscaye, P.E., Flagg, C.N., Falkowski, P.G., 1994. The shelf-edge exchanges processes experiment, SEEPII: an introduction to hypotheses, results and conclusions. Deep-Sea Research $41(2 / 3), 231-252$.

Chang, J., Chung, C.C., Gong, G.C., 1996. Influences of cyclones on chlorophyll- $a$ concentration and Synechococcus abundance in a subtropical western Pacific coastal ecosystem. Marine Ecology Progress Series 140, 199-205.

Cho, B.C., Azam, F., 1988. Major role of bacteria in biogeochemical fluxes in the ocean's interior. Nature 332, 441-443.

Dickey, T.D., Chang, G.C., Agrawal, Y.C., Williams III, A.J., Hill, P.S., 1998a. Sediment resuspension in the wakes of Hurricane Edouard and Hortense. Geophysical Research Letters 25, 3533-3536.

Dickey, T.D., Frye, D., McNeil, J., Manov, D., Nelson, N., Sigurdson, D., Jannasch, H., Siegel, D., Michaels, A., Johnson, R., 1998b. Upper ocean temperature response to Hurricane Felix as measured by the Bermuda Testbed Mooring. Monthly Weather Review 126, 1195-1201.

Dickey, T., Frye, D., Jannasch, H., Boyle, E., Manov, D., Sigurdson, D., McNeil, J., Stramska, M., Michaels, A., Nelson, N., Siegel, D., Chang, G.C., Wu, J., Knap, A., 1998c. Initial results from the Bermuda Testbed Mooring Program. Deep-Sea Research 45, 771-794.

Dickey, T., Granata, T., Marra, J., Langdon, C., Wiggert, J., Chai, Z., Hamilton, M., Vazquez, J., Stramska, M., Bidigare, R., Siegel, D., 1993. Seasonal variability of bio-optical and physical properties in the Sargasso Sea. Journal of Geophysical Research 98, 865-898.

Dickey, T.D., Nelson, N., 1996. In the eye of the storm: Bermuda mooring records hurricane's passage. US-JGOFS Newsletter, September, pp. 5, 6 .

Ducklow, H.W., Carlson, C.A., 1992. Oceanic bacterial production. In: Marshall, K.C. (Ed.), Advance in Microbial Ecology. Plenum Press, New York, pp. 113-181.

Eppley, R.W., Chavez, F.P., Barber, R.T., 1992. Standing stocks of particulate carbon and nitrogen in the equatorial Pacific at $150^{\circ} \mathrm{W}$. Journal of Geophysical Research 97 (C1), 655-661.

Fuhrman, J.A., Azam, F., 1982. Thymidine incorporation as a measurement of heterotrophic bacterioplankton production in marine surface waters: evaluation and field results. Marine Biology $66,109-120$.

Gong, G.C., Chen, Y.L.L., Liu, K.K., 1996. Chemical hydrography and chlorophyll- $a$ distribution in the East China Sea in summer: implications in nutrient dynamics. Continental Shelf Research 16 (12), $1561-1590$.

Gong, G.C., Liu, K.K., Pai, S.J., 1995. Prediction of nitrate concentration from two end member mixing in the Southern East China Sea. Continental Shelf Research 15, 827-842.

Gong, G.C., Shyu, C.Z., Shiu, W.H., Liu, K.K., 1992. Temperature fluctuation of the cold eddy off northeastern Taiwan: June-December, 1990. Acta Oceanographica Taiwanica 28, 118-127.

Hobbie, J.E., Daley, R.J., Jasper, S., 1977. Use of nuclepore filters for counting bacteria by fluorescence microscopy. Applied Environmental Microbiology 33 (5), 1225-1228.

Jickells, T.D., 1998. Nutient biogeochemistry of the coastal zone. Science 281, 217-222.

Levitus, S., 1982. Climatological atlas of the world ocean. NOAA professional paper.

Mantoura, R.F.C., Martin, J.M., Wollast, R., 1991. Ocean processes in global change. Wiley, New York.

McGillicuddy, D.J., Robinson, A.R., Siegel, D.A., Jannasch, H.W., Johnson, R., Dickey, T.D., McNeil, J.D., Michaels, A.F., Knap, A.H., 1998. New evidence for the impact of mesoscale eddies on biogeochemical cycling in the Sargasso Sea. Nature 394, 263-266.

Parsons, T.R., Maita, Y., Lalli, C.M., 1984. A manual of chemical and biological methods for seawater analysis, Pergamon Press, New York, p. 173.

Ritzrau, W., Graf, G., 1992. Increase of microbial biomass in the benthic turbidity zone of Kiel Bight after resuspension by a storm event. Limnology and Oceanography 37 (5), 1081-1086.

Sakshaug, E., Ray, F., Slagstad, D., 1995. Wind forcing of marine primary production in the northern atmospheric low-pressure belt. In: Skjoldal, H.R., Hopkins, C., Erikstad, K.E., Leinaas, H.P. (Eds.), Ecology of Fjords and Coastal Waters. Elsevier Science, New York, pp. 15-25.

Sakshaug, E., Slagstad, D., Holm-Hansen, O., 1991. Factors controlling the development of phytoplankton bloomsin the Antarctic Ocean - a mathematical model. Marine Chemistry 35, 259-271. 
Shaw, P., 1992. Shelf circulation off the southeast coast of China. Review of Aquatic Science 6 (1), 1-28.

Shiah, F.K., 1999. Diel cycles of heterotrophic bacterioplankton abundance and production in the ocean surface waters. Aquatic Microbiol Ecology 17 (3), 239-246.

Shiah, F.K., Kao, S.J., Liu, K.K., 1998. Bacterial production in the western equatorial Pacific: implications of inorganic nutrient effects on dissolved organic carbon accumulation and consumption. Bulletin of Marine Science 63 (3), 795-808.

Shiah, F.K., Gong, G.C., Liu, K.K., 1999. Temperature vs. substrate limitation of heterotrophic bacterioplankton production across trophic and temperature gradient in the East China Sea. Aquatic Microbiol Ecology 17 (3), 247-254.

Shiah, F.K., Liu, K.K., Kao, S.J., Gong, G.C., 2000. The coupling of bacterial production and hydrography in the southern East China Sea: Spatial patterns in spring and fall. Continental Shelf Research 20, 459-477.

Tang, T.Y., Lee, D.W., 1996. Semi-diurnal tide on the shelf break in northeast Taiwan. Terrestrial Atmospheric and Oceanic Science 7, 133-148.

Wong, G.T.F., Chao, S.Y., Li, Y.H., Shiah, F.K., 2000. The Kuroshio Edge Exchange Processes (KEEP) - an introduction to hypotheses and highlights, Continental Shelf Research 20, 335-347. 